\title{
The influence of Learning Techniques and Schemata Levels in Ability to Read English Academic Text
}

\author{
Marhany Malik ${ }^{1)}$, Emzir $^{2)}$, Sabarti Akhadiah ${ }^{3)}$ \\ 1) Universitas Islam Negeri Alauddin Makassar, Makassar, Indonesia \\ E-mail:marhany_malik@yahoo.com \\ ${ }^{2)}$ Universitas Negeri Jakarta, Jakarta, Indonesia \\ E-mail: emzir.pb@gmail.com \\ ${ }^{3)}$ Universitas Negeri Jakarta, Jakarta, Indonesia \\ E-mail: sabartiakhadiah@yahoo.com
}

\begin{abstract}
The aim of this study is to find out the effects of learning techniques and the levels of the schemata of the ability in reading English academic texts of Islamic Studies. This research was quasi-experimental, involved 60 samples of students of Tafsir-Hadis Departement, The first semester of 2012/2013 academic year. Faculty of Ushuluddin and Philosophy, UIN (State Islamic University) Alauddin Makassar. The finding that there is an interaction effect between learning techniques and the levels of the schemata of Islamic studies toward the students' ability in reading English academic texts.
\end{abstract}

Keywords: Learning Techniques; Schemata of Islamic Studies; Ability to Read English Academic Texts

\section{INTRODUCTION}

The purpose of teaching English in Indonesia is to develop language skills and communicate orally and in writing in four skills: listening, speaking, reading and writing to face the development of science and technology Science and Technology) in the globalization era.

Furthermore, the purpose of teaching English at university level, non-English majors is to equip students to understand the contents of textbooks and other referral sources written in English. This objective is in line with the demands of mastery of science and technology, most of which are still written in English especially in the global era (Kaplan, 2000: 283).

English skills can also be elaborated in detail, that understands the lectures presented in English, record lectures delivered in English, orally communicate with lecturers or students in English and write English when communicating with foreigners around the world via e-mail, facebook, twitter, blog, and so forth.

The ability to read is a receptive ability in capturing ideas and ideas to read. Reading is one of the most important skills in learning the language, in addition to listening, speaking, and writing (Harris, 1969: 14). Reading skills are indispensable in terms of acquiring information and increasing the knowledge insight that is growing very rapidly. The print media or books that are the source of such information are mostly written in English. Reading is an equally valuable skill for lecturers and students. Strevens (1977: 64) asserts that reading is considered a very important skill for students and teachers, since reading provides access to a large number of language experiences, and opens the window to a normal tool for continuing his personal education.

In order to be able to read and understand an English text, it requires a variety of knowledge, whether it is knowledge related to the language itself (linguistics) such as vocabulary, grammar, sentence or previously possessed knowledge about reading 
contents known as schematic or initial knowledge. A schema is a well-known mental model used to organize memory, focusing on interpreting experiences, and codifying actions. Yule states that a scheme is a pre-existing structure of knowledge in one's memory (Yule, 1996: 83). Piaget uses the term scheme (plural is schemata) to refer to the cognitive structure that individuals use to adapt and organize the environment (Parsons et al., 2001: 36).

Anderson et, al., States that: "Reading is a process in which information from the text and knowledge possessed by readers of the act together to produce meaning" (1984: 8). Reading is a process in which information from the text and knowledge possessed by the reader cooperates in producing meaning. They further affirm that; "Good readers skillfully integrate into the text with what they already know" (Anderson et, al., 1984: 8). Good readers are able to integrate information from the text with what they already know. A reader understands a message when he is able to bring a schematic into the mind that provides a good description of the objects and events described in the message.

What is the real condition of teaching English at the State Islamic University (UIN) 'Alauddin' Makassar? In this college, English learning has progressed and progressed. English is a compulsory subject for all majors, including students majoring in Tafsir-Hadith existing in Ushuluddin Faculty and Philosophy, Alauddin Makassar State Islamic University (UIN).

Teaching English in college is integrated into four skills, and focus on "reading" (reading). In the Department of Tafsir-Hadith, reading material relates to "Islamic Studies" (Islamic Studies) covering several topics about Islam. English is presented in the first year of two semesters, meant that by the end of the second year, students actually have English functional skills that are one of the skill capital to support their studies in subsequent years, and the emphasis is being able to read and understand English texts, especially reading about Islamic studies. In reality, however, these expectations are not satisfactory, among 60 students only 10\% - 20\% (6 to 12 students) who are able to read and understand reading about Islamic studies in English. This is allegedly among other things because their knowledge or schemata about low Islamic studies, teaching techniques applied by lecturers are less varied, and so forth.

Howell quotes Roller's notion that knowledge of the topic of the reading that is read needs to be mastered so that the reader gives the right reaction to the reading material. The better the knowledge is mastered by the reader, the more prepared it will be to understand the topic of the existing reading material. A student or student who does not have a basic knowledge of the topics in the reading, then he will not be able to understand the contents of the reading (Howell et al., 1993: 186). It can be said that if students or students of TafsirHadith who have knowledge about Islamic Studies are good, they will easily understand the reading written in English, and vice versa.

This expectation is also not fully achieved because it is influenced by several factors, such as the low interest of students studying English, faculty, student, teaching materials, and the approaches, methods, strategies or techniques applied by the teacher, by Winkel (1991: 200) argues that there are two factors in macro that affect learners in the learning process activities, namely internal factors; in the form of intellectual factors, motivation attitude, intelligence, emotional, interest, learning style of learners, and external factors in the form of teaching materials, learning resources, and teacher creativity factors in choosing strategies, methods and teaching techniques.

Based on the above explanation, the researcher is interested to examine how the influence of learning techniques and the level of schematic or knowledge of Islamic studies students of the Department of Tafsir-Hadith to their ability to understand reading English-language academic texts, about Islamic studies.

Researchers use Jigsaw learning techniques and STAD learning techniques (Student Teams Achievement Divisions). Both techniques are used to see which techniques have a better influence on the ability to read academic texts in English, either for students who have high schemata or knowledge of Islamic studies as well as those who have a schema of Islamic studies are low. Given that the two techniques are cooperative learning methods, each technique has its own advantages and disadvantages, similarities and differences. The advantages of Jigsaw learning techniques because students work together in a heterogeneous team and have "expert groups", while STAD learning techniques are learned in groups or groups only, without any "expert group". Ability to Read English Academic Text

Ability is an observable power or strength that is the result of learning (Gagne, et al., 1992: 43). Furthermore, Gagne (1977: 51) says a process of forming a process that takes place continuously and in a long time. Gronlund and Linn lay as the ability of the old learning process (1990: 11). In line with the ability is the understanding of competence. 


\section{Journal of Education, Teaching and Learning \\ Volume 2 No 2 September 2017. Page Number 259-267 \\ p-ISSN: 2477-5924 e-ISSN: 2477-4878}

Savignon says that the specific and specific context (Savignon, 1983: 3).

Referring to the understanding of the above competencies, then the notion of ability by Gagne is itself. Equality of understanding of competence with these capabilities can be seen from the existence of three important elements that exist in both understanding competence and understanding of ability, namely the means or ability: (1) a thorough skills or result of complete learning, (2) arise through a performance, and (3) ) the existence of benchmarks or criteria. So there are five categories of learning outcomes that result from a performance, namely: intellectual skills, cognitive strategies, verbal information, motion, and attitude.

A person's ability in understanding the ability to hear, read, speak, and write. The four speaking abilities are then divided into two, namely receptive ability, reading and reading ability, and productive ability, speech and writing skills.

Some linguists have given different reading restrictions, but they have a similar focus. Reading is an activity to get a writer's message contained words or writing in unity that gave rise to meaning. Reading is also given limitations to understand the meaning of printed or written materials and interpret the intent contained therein (Finnochiaro and Bonomo, 119). Reading is the ability to interpret symbols in both written and printed form (Mitchell, 1982: 1).

Nutall (1985: 2) has given the restrictions on reading, which use terms in groups that can be divided into 3 (three) layers, namely: a) understanding, interpreting, interpreting, interpreting, and so on b) decode (decode ), sound/decipher, identify, and so on, and c) articulate, say, sound, and so on. Reading involves various aspects, such as visual, mental, linguistic, metacognitive, and other aspects with complex mechanisms that lead to the understanding of a written text in its various forms (Harris, 2001: 18).

Reading activities involve physical and mental activity. Both activities are interrelated functionally. From an interaction point of view, reading is a dynamically related and complex physical and mental activity, is a form of communication. This communication is silent communication primarily in adult life (Pugh, 1978: 1) between writers as messengers with readers as processors and recipients through written text media. The author delivers the message into text through encoding on one side, and on the other hand, the reader processes the text to reconstruct the author's message through the decoding process (Nuttall, 1985: 4).
Reading activity originates from visual physical activity, which includes activities involving eye movements, eye recognition, and activities linking words with the experiences it represents (Miller, 1989: 21).

As a continuation of visual physical activity, the activity also involves mental activity, which includes understanding what reads, assesses, and uses the knowledge and attitude of the reading activity in the reader's life.

The ability to read to understand an English academic text reading is a person's ability to reconstruct the meaning contained in the reading material. Different understanding skills because each individual has different experiences, thinking, and reading strategies. Reading activities demand the use of all the abilities that readers have in exploring the meaning of reading material (Petty and Jensen, 1980: 216). The importance of knowledge play in reading Weaver also confirms that reading is the acquisition of meaning through the process of combining information obtained from reading material with the knowledge that the reader has (Weaver 1990: 175).

To measure the ability to read English academic texts, Richard Anderson argues that reading ability can be measured through the following questions:

- The level of literal understanding: (a) what is the action on the story ?, (b) who is the main characters ?, and (c) where does it take place?

- The level of interpretation: (a) what is the author trying to convey ?, (b) what is the underlying theme ?, and (c) what is this fact as it is known?.

- The level of evaluation: (a) what symbols are presented ?, (b) what can be inferred what is being said ?, and (c) what are the evidences for making the following generalizations? (Anderson, 1981: 160).

Based on some of the above opinions, it can be concluded that the reading is a snare that involves the reader, text readings and messages conveyed by the author. A person may be deemed read when he or she has received a message or explicit or implied information submitted by the author.

The ability to read English-language academic texts that the author intends in this study is the ability or ability of students to capture information or ideas submitted by the author through texts or reading in English, in this case, is a reading of Islamic studies including literal, inferential and evaluation of text.

Jigsaw and STAD Learning Techniques

Techniques in teaching is a way or tool that aims to improve efficiency in the implementation of 
learning that is by setting the steps that must be followed in sequence. By using a technique in teaching, a teacher can create a teaching scenario and can anticipate problems that will arise so that teachers can prepare themselves as early as possible.

In the process of learning, known some terms that have similarities of meaning, namely: approach, method, technique, and so forth.

According to Edward Anthony in Brown, the term approach, method and technique are to have different concepts. An approach is a number of assumptions that advance on the nature of language, learning, and teaching. The method is described as the overall planning for the systemic representation of the language based on the chosen approach. Further techniques (techniques) are specific activities implemented in a classroom consistent with the method chosen (Brown, 2007: 14).

There are two learning techniques used in this study that are Jigsaw and STAD learning techniques (Student Team-Achievement Divisions). Jigsaw

Jigsaw's teaching technique was developed by Elliot Aronson and his colleagues in 1978 . Furthermore, a more practical and easy form of Jigsaw adaptation is the Jigsaw II developed by Slavin. Jigsaw II is appropriately used if the material to be studied is in the form of a written narrative, as well as the purpose of learning more to the mastery of the concept than the mastery of ability.

In Jigsaw learning, the students work in a heterogeneous team. They are given the task of reading several chapters or units and are given "expert sheets" consisting of different topics and should be the focus of attention of each team member as they read. After all finished reading, the students from different teams and have the same topic focus met in the "expert group" to discuss their topic about thirty minutes. The experts then went back to their team and took turns teaching one team on their topic. Lastly, the students receive an assessment that covers all topics, and the quiz score will be the team score. The scores that the students are contributing to his team are based on an individual development score system, and the students whose team scores the highest will receive certificates or other forms of team recognition. Thus, the students are motivated to study the material well to work hard in their expert group to help their team do their job well. The key to the Jigsaw method is interdependency, each student is dependent on his teammates to be able to provide the required information that can perform well at the time of assessment (Slavin, 2010: 237).
In line with Slavin, Brown (Brown, 2007: 233) explains about Jigsaw:

"Jigsaw techniques are a special form of information gap in which each member of a group is given some specific information and objectives the goal is to pool all information to achieve some objectives. Imagine four members of a group each with application form, and on which form different information is provided. As students ask each other questions, they eventually complete all the information on the form. Or you might provide maps to students in small groups, each student receiving different sets of information. The goal for beginners might be simply to locate everything correctly, and for intermediate learners to give directions on how to get from one place on the map to another, requiring a collaborative exchange of information in order to provide complete directions.

Brown's explanation above describes the Jigsaw technique that divides several students into small groups, then each individual is given a different topic for their discussion, then converts to "expert groups" to deepen their understanding of the text they have back into their group to convey the results of his understanding to his group's friends.

From the above explanation, it can be understood that Jigsaw learning makes the students motivated to study the material well to work hard in expert groups, and can help his team do their job well,

The key to the Jigsaw method is interdependency, each student is dependent on his teammates to be able to provide the necessary information and be able to perform well at the time of assessment.

The steps of learning Jigsaw technique in reading academic texts in English, namely: a) Students are divided into several groups and each group consists of 4-5 people heterogeneous, b) Lecturers distribute material group and each group member has a focus of the topic, c) Students read and understand the material given, d) Lecturers collect students based on their material focus (expert team) to discuss the focus of their topic, namely: to determine the main idea, to seek detailed information, specific information and general description (e) The lecturer returns them to their respective initial group, f) Each student sends and discusses the results of their understanding from the expert team to the members of their group.

STAD (Student Team-Achievement Divisions)

Students Teams-Achievement Divisions (or Student Teachers') learning techniques or abbreviated with STAD, developed by Rober Slavin and his 


\section{Journal of Education, Teaching and Learning \\ Volume 2 No 2 September 2017. Page Number 259-267 \\ p-ISSN: 2477-5924 e-ISSN: 2477-4878}

friends at John Hopkin University, is one type of cooperative learning where the emphasis is on activity and interaction between learners, to motivate each other and help each other in mastering the subject matter to achieve maximum performance.

This technique is one of the simplest methods of cooperative learning and is the best model for the beginning for new teachers using a cooperative approach.

According to Slavin (2005: 143) STAD learning techniques consist of five stages: (1) class presentation stage, (2) stage of group work (teams), (3) individual test stages (quizzes), (4) stages of individual development score scores, and (5) group recognition.

The STAD technique learning steps in reading academic texts in English, namely: a) Students are divided into several groups and each group consists of 4-5 people heterogeneously, b) Lecturer distributed material in each group, c) students read and understand the material given, they discuss their topics, namely: determining the main idea, seeking detailed information, certain information and general description of the reading, in this case the reading of Islamic studies, and likening the perception of the material they received from lecturers, d) Students deliver their group work.

Schematic and Ability to Read English-Academic Text of English Students

The scheme is an abstract knowledge structure, in the sense that the scheme looks for what is known about different cases in many ways (Anderson et al., 1984: 42).

Anderson is a psychologist who introduced the schemata theory to the educational community. $\mathrm{He}$ introduced that the schemata provide a form of representation of complex and constructive knowledge, for the first time providing a principled explanation of how old knowledge might influence the acquisition of new knowledge. Scheme theory is directly applied in understanding the reading process, which is used as an important counterweight to the bottom-up approach in reading.

The schema theory approach in reading emphasizes that reading involves both the butter-up information of observed letters that are incarnate in the eye and the use of top-down knowledge to construct a meaningful representation of the text content (Brewer: 2008). Schemata is a knowledge structure contained in a person's memory that is related to new information and can help him understand the information.

Modern scheme theorists believe that schema is a data structure of generational ideas stored in memory, consisting of variables and slots. On the basis of such a principle, the meaning does not exist in spoken or written language, but in the reader's mind, depending on the activation of the brain scheme that controls the structure or pattern of the basic displacement commanded through the processed and processed bottom-up data and the driven top-down concept and processed. According to schema theory, in reading, the use of bottom-up and top-down processing is simultaneous (Stott, 2001: 1).

Scheme to understand a text is an interactive process between the background knowledge of the reader and the text. Efficient understanding requires the ability to link textual material with the knowledge one has. Understanding words, sentences, and whole texts involve more than relying on a person's knowledge of language.

Every human being has the rules or categorical scripts they use to interpret. New information is processed according to how he or she adapts to these rules, known as schemes. This scheme can not only be used to interpret, but also to predict the situation occurring in our environment. The scheme is not only important in interpreting information, but it is also important in deciphering how the information is presented (Wimayer, 2007: 1). Widdowson (1983: 54) asserts that schematics are constructs or configurations of knowledge placed on events to bring them into alignment with patterns familiar to experience and belief. This scheme thus serves as a tool for categorizing and composing information so that it can be interpreted and mastered. Yule states that a schema is a pre-existing structure of knowledge in one's memory.

Nunan (1993: 115) argues that schemata are called by the term of early knowledge, meaning the knowledge of the world that the reader uses in interpreting written or spoken language. According to Hyde \& Bizar (1989) in Parsons, et.al (2001: 259) contemporary learning theory embraces theoretical scheme as an attempt to explain how information is stored well in long-term memory. Theoretical scheme according to Douchy \& Bouwens (1990) reinforces the nature and purpose of the schemata as fundamental elements and information processing. According to Bigenho and Leinhardt (1992), the schemata is the earliest knowledge network and affects the quantity and learning skill. Meanwhile, according to Leinhardt, Alexander, Kulikuwich, and Schule in the Parson (2001: 259), because this theory asserts that our initial knowledge can facilitate or enhance the transfer of a learning task, the initial 
knowledge may hinder or interfere with our acquisition of new information.

Reading foreign texts, some linguists, among them Bernhardt (1986), Carrel, Devine \& Eskey (1988), and Rumelhart (1977) view reading as interactive. The reader interacts with the text to create meaning because the reader's mental processes work together on different levels. According to Hosenfeld, as quoted by Barnett (1988: 1), the level of reader's understanding of the text is determined by how good the reader variables are: the level of interest in the text, the purpose of reading the text, the knowledge of the topic, the ability of the foreign language awareness of the process reading, and level of desire with text variables, such as text type, structure, syntax, and vocabulary, as proposed by Brown (2007: 358): the reader brings information knowlege, emotion, experience, and culture to the printed word ( schema). Skill in reading depends on the efficient interaction between linguistic knowledge and knowledge of the world ". The reader brings knowledge, information, emotion, experience, and culture printed (scheme). Reading skills depend on the interplay of linguistic knowledge and the knowledge of the reader's world.

The main function of the schemata in reading a text is editing and planning. Editing is selecting, abbreviating, abstracting, composing, organizing, and filtering out reading materials. Screen selection, abbreviation, and depreciation are the first stages of editing. The preparation, organization, and screening of the scheme is the second stage of editing. The first phase of editing accommodates schema-related information and filters out irrelevant ones. Accommodated content is not reproduced from the original but from the abstraction of its basic meanings. In other words, the first phase of editing converts the text meaningfully, and the second stage of editing reorganizes and modifies received material based on the knowledge of the special scheme that the reader has (Xuping Xie, 2005: 69).

\section{RESEARCH METHOD}

The method used in this research is the experimental method with the design of two-way variance analysis of ANAVA with $2 \times 2$ factorial design, a significant level, $\alpha=0.05$. This research was conducted on students of Tafsir-Hadith, first semester of 2012/2013, Faculty of Ushuluddin and Philosophy of State Islamic University (UIN) Alauddin Makassar. Treatment procedure through three stages, namely: preparation, implementation, and treatment. This study uses two types of instruments, namely (1) the level of schematic or knowledge of Islamic studies of students, and (2) the ability to read academic texts in English students/coed. The two instruments are analyzed by (1) descriptive analysis, used to determine the mean, mode, median, variance, minimum, maximum and deviation values, and (2) normality test using Lilifors test, homogeneity of population test by using Barlett test. The result of the analysis shows that there is interaction, then the analysis is continued with Tuckey test.

Variable in this research is independent variable (independent variable) and dependent variable (dependent variable). There are two independent variables, namely: 1) instructional techniques, and 2) the level of schematic or knowledge of Islamic studies, while the dependent variable is the ability to read academic texts in English.

The learning technique used is Jigsaw and STAD technique. The subjects were divided into two groups: one group of experiments taught by Jigsaw learning technique, and one was a control group with STAD learning technique. The level of schemata referred to in this study is the level of knowledge of Islamic studies high and low.

\section{RESULT AND DISCUSSION}

The results showed that the variables of learning technique and the level of schemata about Islamic studies have a significant influence on the ability of students to read academic texts in English.

The discussion of the research findings and the results of hypothesis testing will be described as follows:

A. Ability to read academic texts in English students who are taught with Jigsaw learning techniques higher than students who were taught by STAD learning techniques.

The results of testing on the research hypothesis stating that there are differences in the ability to read English-language academic texts about Islamic Studies students who were taught with jigsaw learning techniques with groups of students who were taught with STAD learning techniques can be accepted.

This statement implies that the ability to read academic English texts on Islamic Studies groups of students taught by Jigsaw learning techniques is higher than the ability to read 
academic texts in English groups of students who were taught by STAD learning techniques.

This conclusion is supported by the acquisition of descriptive statistics, showing the average reading ability of English academic texts on Islamic Studies taught by jigsaw technique of 29.73 is higher than the average reading ability of academic texts in English group of students taught by STAD learning technique 28.03 .

Thus it can be stated that learning English for reading in college that is not English majors, especially on Fakulltas Ushuluddin and Philosophy where this research is conducted, the use of Jigsaw learning technique is better than the use of STAD learning techniques.

Jigsaw learning techniques are cooperative learning techniques that can foster the responsibilities of students, encourage them actively and mutually assist in mastering the lecture material to achieve maximum performance and finish it in groups.

The presence of Jigsaw learning techniques can improve the learning conditions, so that the learning process becomes more fun and meaningful for both lecturers and students.

B. The influence of significant interaction between learning techniques and the level of schemata on the ability to read academic texts in English students/coed.

Based on the result of the research, it can be stated that the difference of students' ability to read English academic texts on Islamic Studies is determined by differences in schematic level and instructional techniques which indicate: (1) for groups of students who have schematic level / knowledge about Islamic studies high, the ability to read academic texts in English students who are taught with Jigsaw learning techniques have an average grade of 35.11 higher than students / students who are taught by STAD technique, their average score is 25.78 , (2) for students which has a low level of sciences/knowledge of Islamic studies, the ability to read academic texts in English students taught by Jigsaw learning techniques, their average score is 26.00 lower than that of students taught by STAD learning techniques, their average is 29.44 .

The effect of differences in the ability to read academic texts in English students after seeing the level of their schemata from each group is described based on the findings of research results as follows:

C. For students who have high level of schemata, the ability to read academic texts in English college students who follow the lectures with Jigsaw learning techniques higher than students who follow the lectures with STAD techniques.

The results of testing on the hypothesis of research that states that for groups of students who have high level of science or knowledge of Islamic studies, there is a difference in the ability to read English-language academic texts for students who are taught by jigsaw learning techniques with students who are taught by learning techniques STAD.

The statement is reinforced by the descriptive statistic scores, that for groups of students with high schematic level, the ability to read English academic texts on Islamic Studies students who are taught by Jigsaw learning techniques have an average grade of 35.11 higher than reading ability English-speaking academic tuition of students taught by STAD technique, their average score is 25.78 .

Thus, it can be concluded that in learning English for reading in college, which is not English department, especially at Fakulltas Ushuluddin and Philosophy where this research is conducted, the use of Jigsaw learning technique is better than using STAD learning technique, especially for students -master who has high schemata.

D. For students who have low level of schematic, the ability to read academic text in English students/college students who follow the lectures with STAD learning techniques higher than students/college students who follow the lectures with techniques Jigsaw.

The result of the test on the research hypothesis stating that for groups of students who have low level of knowledge of Islamic studies, there is a difference in the ability to read academic texts in English about Islamic Studies for students taught by jigsaw learning techniques with college students who are taught with STAD learning techniques.

The statement is reinforced by the acquisition of descriptive statistic scores, that for groups of students who have low levels of schemata, the ability to read English-speaking academic texts of students taught by STAD learning techniques has an average value of 29.44 higher than the ability to read academic texts British college students taught by Jigsaw technique, their average score is 26.00 .

Thus, it can be deduced that in learning English for reading in college, which is not English department, especially at Fakulltas 
Ushuluddin and Philosophy where this research is conducted, the use of instructional techniques should be varied, Jigsaw and STAD can be used considering that student has individual differences, among others, have high or low schemata.

\section{CONCLUSIONS}

Based on the discussion about the results of research on the influence of learning techniques and the level of schemata on the ability to read academic texts in English on Islamic Studies, it can be drawn some conclusions as follows:

1. The ability to read English academic texts on Islamic Studies in groups of students who were given Jigsaw learning techniques higher than the group of students who were given STAD learning techniques.

2. There is a significant interaction effect between learning techniques and the level of schemata or knowledge of Islamic studies on the ability of students to read academic texts in English.

3. For college students who have high level of knowledge or knowledge of Islamic studies, the ability to read academic texts in English groups of students who are given Jigsaw learning techniques higher than the group of students who were given STAD learning techniques.

4. For students who have low level of knowledge or knowledge of Islamic studies, the ability to read academic texts in English groups of students who are given STAD learning techniques higher than the group of students who were given Jigsaw learning techniques.

\section{REFERENCES}

Anderson. (1981). Efficient Reading: A Practical Guide. Sidney: McGraw-Hill Book Company.

Anderson, Richard et. al. (1984). Becoming a Nation of Readers: The Report of Commission on Reading.

Barnett, Marva A. (1988). Teaching Reading in a Foreign Language. Washington DC: Eric Clearinghouse on Languages and Linguistics.

Brown, H. Douglas. (2007). Teaching by Principles: An Interactive Approach to Language Pedagogy. New Jersey: Prentice Hall Regents.

Finocchiaro, M., and Bonomo, M. (1973). The Foreign Language Learner: A Guide for Teachers. New York: Regents Publishing Company.

Gagne, R.M. (1977). The Conditions of Learning. New York: Holt, Rinehart, and Winston.
Gagne, R.M., L.J Leslie, and W.W.Wager. (1992). Principles of Instructional Design. Worth: Harcourt Brace Jovanovich.

Grondlund, N.E., and R.L.Linn. (1990) Measurement and Evaluation in Teaching. New York: McMillan Publishing Company.

Harris, David P. (1969). Testing of English as a Second Language. New York: Mc. Graw-Hill Inc.

Harris, Pauline, et.al. (2001). Reading in the Primary Years. Riverwood: Social Science Press.

Howell, Fox, and Morehead. (1993). Curriculum Based Evaluation. California: Wardworth, Inc.

Kaplan, Robert B. (2000). "Why is English a Global Language? Problems and Perplexities," Language in the Global Context. Ed. Ho Wah Kam and Christopher Ward. Singapore: SEAMEO Regional Language Centre.

Miller, Wilma H. (1971). Identifying and Correcting Reading Difficulties in Children. New York: The Centre for Applied Research in Education.

Mitchell, D.C. (1982). The Process of Reading: A Cognitive Analysis of Fluent Reading and Learning to Read. Chichester: John Willey and Sons.

Nunan, David. (1993). Introducing Discourse Analysis. London: Penguin Books Ltd.

Nutall, Christine. (1985). Teaching Reading Skills in a Foreign Language. London: Heinemann Educational Books.

Parsons, Richards D. et.al. (2001). Educational Psychology: A Practitioner-Researcher Model of Teaching. Canada: Wardsworth Thompson Learning, Inc.

Petty, Walter T. and Julie M. Jensen. (1980) Developing Children's language. Boston: Allyn and Bacon, Inc.

Pugh, A.K. (1978). Silent Way: An Introduction to It's Study and Teaching. London: Heinemann Educational Books.

Savignon, S.J. (1983). Communicative Competence: Theory and Classroom Practice. California: Addison-Wesley Publishing Company.

Slavin, Robert E. (2010). Cooperative Learning: Teori, Riset dan Praktik, Diterjemahkan oleh Narulita. Bandung: Penerbit Nusa Medoa.

Stott, Nigell. (2001). Helping ESL Students Become Better Readers: Schema Theory Applications and Limitations. (http://iteslj.org/Articles/Stott-Schema.html).

Streven, Peter. (1977). New orientation in the Teaching of English. Great Britain: Oxford University Press. 
Weaver, Constance. (1990). Understanding Whole Language. Toronto: Irwin Publishing.

Widdowson, H.G. (1983). Learning Purpose and Language Use. Oxford: Oxford University Press.

William, F. Brewer. (2008). Learning Theory Schema Theory.

Wimayer, Sharon Alayne. (2007). Schema Theory: An Introduction.

Winkel, WS. (1991). Psikologi Pengajaran. Jakarta: Grasindo.

Yule, George. (1996). Pragmatics. Oxford: Oxford University Press.

Xuping Xie. (2005). The Influence of Schema Theory on Foreign Language Reading Comprehension. The English Teacher Vol. XXXIV. 